\title{
EFFECTIVENESS OF THE TEXTBOOK ON STRUCTURE AND FUNCTION OF CELlS IN REPRODUCTIVE SYSTEM MATERIAL
}

\author{
Ruqiah Ganda Putri Panjaitan ${ }^{1 *}$, Titin $^{2)}$, Yohanes Gatot Sutapa Yuliana ${ }^{3)}$ \\ 1) Universitas Tanjungpura, Pontianak, Indonesia \\ ${ }^{*}$ E-mail: ruqiah.gpp@gmail.com \\ 2) Universitas Tanjungpura, Pontianak, Indonesia \\ E-mail: titin@fkip.untan.ac.id \\ 3) Universitas Tanjungpura, Pontianak, Indonesia \\ E-mail: gatot@fkip.co.id
}

\begin{abstract}
A well-conducted learning activity is supported by the availability of teaching materials, among many other supportive aspects. One of the most common teaching materials is textbook. This study aims to find out the effectiveness of the textbook on the structure and function of cells in reproductive system material for eleventh-grade students in high school. This study applied a descriptive method, and the data analysis used the Gregory test involving two validators. Three aspects that had been validated are presentation, content, and language consisting of fifteen criteria. The result of validation showed the validity construct for the aspect of the presentation is 1 , the aspect of content is 1 , and the aspect of language is 1 , so the criteria for each aspect are very high. It concluded that the textbook can be used as a teaching material for the structure and function of cells in reproductive system material.
\end{abstract}

Keywords: Textbook; Effectiveness; Structure and Function of Cells; Reproductive System

\section{INTRODUCTION}

Learning is an interaction among learners, teachers, and learning sources under the learning environment atmosphere. In the learning process, learners are assisted by teachers so they can learn well. In other words, there is a process of acquiring knowledge, mastery of skills and characters, and the formation of attitudes and self- confidence of students, also to increase the critical thinking of students (Ongsee and Nuangchalerm, 2019).

The learning process should be in accordance with the curriculum used. The curriculum is a set of plans and arrangements regarding the purpose, content, and material of learning and the methods used to guide the implementation of learning activities to achieve certain educational goals. Consequently, teaching material is inevitably one of the important components to be delivered to students (Chalkiadaki, 2018).

Teaching material plays an important role in the learning process, as a benchmark for achieving an effective and efficient learning process (Purwanto and Rizki, 2015). It is also key to increasing learning outcomes (Asfiah et al., 2013; Suprapti \& Susanti, 2015). Based on its form, teaching material can be divided into print, audio, visual, audio-visual, and multimedia teaching material (Asfiah et al., 2013; Pramana and Dewi, 2014; Amir et al., 2015; Daud and Rahmadana, 2015; Nisa' et al., 2015; Padmapriya, 2015; Suwarni, 2015; Panjaitan et al., 2019a; Panjaitan et al., 2019b; Panjaitan et al., 2019c; Panjaitan et al., 2019d).

The textbook has become the main learning source in the learning process (Mahmood, 2011; Thang et al., 2013; Anisah and Azzah, 2016). The textbook as teaching material contains knowledge which is derived from basic competencies of the curriculum and used by students in the learning process. The textbook can be the best learning resource when properly prepared and used in the learning process (Allehyani et al., 2017). In the preparation of the textbook should pay attention to students' needs, then the textbook provides a guideline for the students to learn effectively (Allehyani et al., 2017). Moreover, the textbook can also be used as a syllabus to determine the benchmark. The contents available in the textbook are supported by relevant assignments and exercises streamline teacher's time 
in the learning process. The textbook also allows students to learn independently (Suwarni, 2015).

The compilation of the textbook is divided into three main parts; the opening section, contents, and closing section. Besides, a few other things are mainly important to consider. A textbook has to be adjusted with Core Competencies (KI), Basic Competencies (KD) and the number of essential topics to comprehend. A textbook also should pay attention to cognitive, affective, and psychomotor aspects of the students, presents a series of learning experiences that include skills, clear learning instructions, illustrations, supporting information, learning exercises, work instructions, and evaluation, where each component integrates with each other. According to the National Education Standards Agency (BSNP, 2014), an effective textbook should cover 3 components; content effectiveness, language effectiveness, and presentation effectiveness.

One of the materials in Biology subject in Senior High School (SMA) is the structure and function of cells in the reproductive system. This topic talks of a wide area of discussion, causes the teacher to challenge with the time constraint. The topic of structure and function of cells in the reproductive system involves presumably broad and difficult discussion for the students. The teacher instead should carefully choose an effective and efficient learning strategy. One learning strategy that can be applied as an alternative to this problem is the use of an appropriate textbook. According to Rahmawati (2015) by applying a textbook, students are expected to apply independent learning patterns, comprehend the material, and be able to solve the questions in textbooks as a practice of problem-solving.

Based on the prior observation, it was found that the textbook used in the learning process by far contains only knowledge about the concepts of cell structure and function in the reproductive system. For this reason, an alternative is needed so that students do not only gain knowledge but also practice skills to take care of their reproductive health and maintain attitudes of avoiding disorders/diseases in the reproductive organs. Consequently, the compilation of textbooks does not only contain basic concepts of the topic about cell structure and function in the reproductive system but also includes the character development values important for the high school students, such as the danger of unwanted pregnancies for teenagers and other positive activities suitable for adults to avoid deviant behavior.

\section{Methodology}

This study applies descriptive methods. Descriptive research is conducted to find out the existence of independent variables, either on one variable or more variables without making comparisons or connection with other variables (Sugiyono, 2015). The instrument used in this study is the textbook validation sheet. The textbook validation sheet is adapted from the assessment instrument of textbooks from BSNP (2014) which consists of three aspects; presentation, content, and language with fifteen criteria.
Data from the validation results will be analysed by using Gregory's test calculations. Content validity shows the extent to which questions, assignments or items in a test or instrument are able to represent the overall and proportional behavior of the sample subject to the treatment. This means that existing instruments reflect the overall content or material being tested or that should be mastered proportionally. Validation is carried out by two experts (Panjaitan et al., 2019a; Panjaitan et al., 2019b; Panjaitan et al., 2019c; Panjaitan et al., 2019d ). In this study, validation was carried out by 2 people consisting of 1 expert in biology, a lecturer and 1 practitioner who works as a biology teacher.

The results of the validation are used as the basis for evaluating the effectiveness of the textbook on the structure and function of cells in the reproductive system. The assessment of the validation sheet was analyzed by calculating the scores obtained. Next, it will be calculated by using a formula to produce validation values. The calculation formula is as follows equation 1 .

$$
V_{C}=\frac{D}{A+B+C+D}
$$

Information:

$$
\begin{array}{ll}
V \mathrm{c} & =\text { Validity construct } \\
A & =\text { Both judges disagree } \\
B & =\text { Judges I agree, judges II disagree } \\
C & =\text { Judges I disagree, judges II agree } \\
D & =\text { Both judges agree }
\end{array}
$$

\section{RESULTS AND DISCUSSION}

\section{A. Results}

The results of the textbook validation on the structure and function of cells in the reproductive system of two validates consisting of three aspects; the presentation aspect consisting of seven criteria, the content aspect consisting of four criteria, and the language aspect consisting of four criteria can be seen in Table I. For the analysis of the results using the Gregory test to determine the effectiveness of the textbook can be seen in Table II.

TABLE II

RESUlTS OF EFFECTIVENESS VALIDATION OF TEXTBOOK

\begin{tabular}{lcc}
\hline \multicolumn{1}{c}{ Aspects } & $\begin{array}{l}\text { Validity } \\
\text { Construct }\end{array}$ & \multicolumn{1}{c}{ Criteria } \\
\hline Presentation & 1 & Very High \\
Content & 1 & Very High \\
Language & 1 & Very High \\
Average & 1 & Very High \\
\hline
\end{tabular}

\section{B. Discussion}

Learning activities can run effectively and efficiently if learning resources are available. One example of a learning resource is teaching materials in the form of textbooks. Textbooks are one of the important components in the learning process because they can provide extraordinary learning experiences (Mahmood, 2011; Thang et al., 2013). Textbooks are books that guide students' learning activities (Suwarni, 2015). Moreover, for teachers, books can be used 
as a reference in a wide variety of subjects. Meanwhile, for students, books can be used not only in schools but also at home to tackle learners' confusion toward some prior materials or those that have yet to be discussed. In addition, the use of books in learning process can encourage learning pattern that was initially teacher-centered to be more student-centered, because learn through textbooks, students are required to look for information they are eager to know, to comprehend a reading text, to reflect understanding in written form and actively participate in learning process (Mahmood, 2011; Thang et al., 2013; Suwarni, 2015).

TABLE I

RESULTS OF TEXTBOOK VALIDATION

\begin{tabular}{|c|c|c|c|}
\hline \multirow{2}{*}{ Aspects } & \multirow{2}{*}{ Criteria } & \multicolumn{2}{|c|}{ Validator } \\
\hline & & 1 & 2 \\
\hline \multirow{7}{*}{ Presentation } & 1. Variety of presentation & 3 & 4 \\
\hline & $\begin{array}{l}\text { 2. Compatibility of written letters (font) in the } \\
\text { textbook }\end{array}$ & 3 & 4 \\
\hline & 3. Learning presentation & 4 & 4 \\
\hline & 4. Picture attraction in the module & 3 & 4 \\
\hline & 5. Presentation technique in the module & 3 & 4 \\
\hline & 6. Completeness of presentation & 4 & 4 \\
\hline & 7. Supporting the presentation of the material & 3 & 4 \\
\hline \multirow{4}{*}{ Content } & $\begin{array}{l}\text { 8. Conformity of the material with the basic } \\
\text { competencies, learning indicators, and } \\
\text { learning purposes. }\end{array}$ & 4 & 4 \\
\hline & 9. Completeness of information provided & 4 & 4 \\
\hline & 10. Conformity with the development of science & 3 & 4 \\
\hline & $\begin{array}{l}\text { 11. The material presented does not violate the } \\
\text { law and legislation }\end{array}$ & 3 & 4 \\
\hline \multirow{4}{*}{ Language } & 12. Readability & 3 & 4 \\
\hline & $\begin{array}{l}\text { 13. Language compatibility with Rules of } \\
\text { Bahasa Indonesia }\end{array}$ & 3 & 4 \\
\hline & $\begin{array}{l}\text { 14. Consistency in the use of terms/ symbols/ } \\
\text { signs }\end{array}$ & 3 & 3 \\
\hline & $\begin{array}{l}\text { 15. The accuracy of writing scientific terms / } \\
\text { foreign names }\end{array}$ & 3 & 4 \\
\hline
\end{tabular}

A good textbook must meet certain standards set by the BSNP to be suitable for implementation in the learning process (BSNP, 2014). In this study, the aspects assessed from the textbook on reproductive system material including aspects of presentation, content, and language.

According to the recapitulation of the validation results on two experts (Table II), the component of effectiveness in a presentation obtained 1 construct validation with very high criteria. This shows that the books developed have been presented in a coherent and good manner. Presentation of learning using reproductive system material books has invited students' participation with the LKPD and evaluation questions. There is also another supportive display of material that aims to generate learning motivation as reflected by the existence of motivational sentences and additional information in the "Did You Know" window section. In the "Did You Know" window section, students are invited to give additional information related to the things they often encounter in their daily lives (Fig. 1). Related to Chamany et al. (2008), it is important because students must be able to make connections (relationships) between what they learn and what they face in their daily lives. In addition, the presentation of the textbook has also been in line with the BSNP, which states that the book should be supplemented by the presence of introductory words, table of contents, and bibliography (BSNP, 2014).
The content eligibility obtains validation of 1 with very high criteria. This means that the material and assignments presented in the textbooks on the structure and function of cells in the reproductive system are in accordance with KI, $\mathrm{KD}$, and learning objectives in the syllabus (Fig. 2). Related to Panjaitan (2019a); Panjaitan et al. (2019b); Panjaitan et al. $(2019 c)$; Panjaitan et al. $(2019 d)$ the teaching material which developed should be consist of $\mathrm{KI}$, KD, and learning objective, also presented learning concepts which explained correctly. The components which are presented in this textbook consist of cell structure and cell function in the reproductive system both owned by men and women which include reproductive organs, gametogonium, hormones, menstrual processes, fertilization, and pregnancy. This textbook as well discusses various abnormalities and diseases in the human reproductive system and other important information about the dangers of unwanted pregnancies for adults without leaving the discussion on positive activities that can be done to prevent the deviance. In addition, this book also provides material on textbooks, syllabus, lesson plans, worksheets, learning media, and assessments that teachers can use in the learning process. The concepts and definitions presented in the book have been adjusted with the development of science and do not violate the legislation. 
The effectiveness of language is equal to the results of validation, of 1 with very high criteria. These results explain that the sentence used in the book is an easily understandable sentence that fits the level of students' thinking and socialemotional development (Fig. 1). The sentences used to convey material are categorized as good and have presented correct Indonesian grammar rules. The spelling used as well as referred to the improved spelling guidelines. Moreover, BSNP (2014) stated the material presented has reflected the complexity and integrity of the meaning, and the use of the terms has been relatively consistent.

kelangsungan hidup bayi. World Health Organization (WHO) merekomendasikan pemberian ASI eksklusif (bayi hanya diberikan ASI tanpa cairan atau makanan lain, kecuali suplemen vitamin, mineral dan atau obat-obatan karena alasan medis) sampai usia enam bulan dan dilanjutkan sampai anak berusia dua tahun. ASI mampu memenuhi semua nutrisi yang dibutuhkan bayi selama enam bulan awal kehidupannya dan masih mampu memenuhi sekitar sepertiga kebutuhan kalori bayi pada usia dua tahun. Selain itu, ASI terbukti mampu memenuhi kebutuhan bayi dari aspek gizi, imunologis (pembentukan sistem kekebalan tubuh), aspek psikologis (interaksi ibu dan anak yang terjadi selama menyusui), pembengkakan otak, aspek ekonomis serta berperan dalam penundaan kehamilan.

Hanya $32 \%$ bayi di Indonesia yang memperoleh ASI eksklusif. Padahal $16 \%$ kematian bayi bisa dicegah apabila bayi diberikan ASI eksklusif. Hebatnya lagi ASI eksklusif dapat mengurangi pendarahan setelah melahirkan, dapat mengurangi resiko terkena kanker ovarium dan payudara.

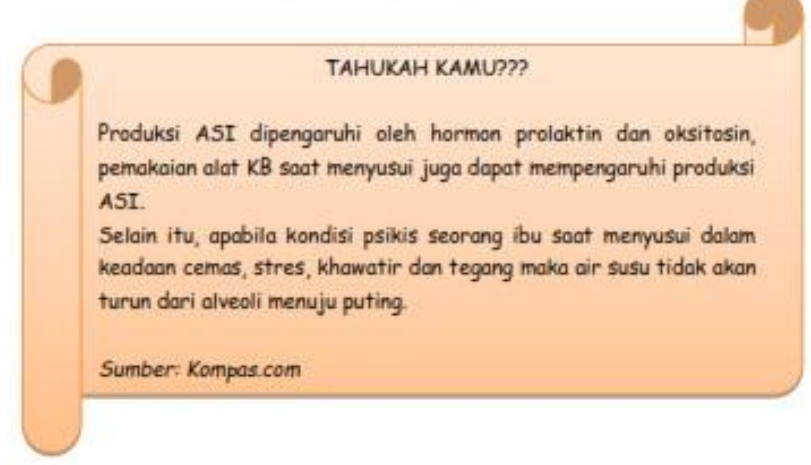

51

Fig. 1 Presentation of motivational sentences and additional information in the "Did You Know" window section

From these three aspects; presentation, content, and language compatibility, the construct validations obtain of 1 with very high criteria. These results indicate that textbooks on the structure and function of cells in the reproductive system material are declared valid and appropriate to be implemented as one of the teaching materials.
B. Kompetensi Dasar

3.12 Menganalisis hubungan antara struktur jaringan penyusun organ reproduksi dengan fungsinya dalam proses reproduksi manusia melalui studi literatur, pengamatan, percobaan dan simulasi.

3.13 Menerapkan pemahaman tentang prinsip reproduksi manusia untuk menanggulangi pertambahan penduduk melalui program keluarga berencana (KB) dan peningkatan kualitas hidup SDM melalui pemberian ASI ekslusif.

4.13 Menyajikan hasil analisis tentang kelainan pada struktur dan fungsi organ yang menyebabkan gangguan sistem reproduksi manusia melalui berbagi bentuk media presentasi.

4.14 Memecahkan masalah kepadatan penduduk dengan menerapkan prinsip reproduksi manusia.

4.15 Merencanakan dan melakukan kampanye tentang upaya penanggulangan pertambahan penduduk dan peningkatan kualitas SDM melalui program keluarga berencana $(\mathrm{KB})$ dan pemberian ASI ekslusif dalam bentuk poster dan spanduk.

\section{Tujuan Pembelajaran}

Pertemuan 1

Siswa mampu:

1. Mengidentifikasi struktur dan fungsi sistem reproduksi manusia

2. Menjelaskan proses pembentukan sperma dan sel telur

82

Fig. 2 Presentation of the material and assignments presented in the textbooks on the structure and function of cells in the reproductive system are in accordance with $\mathrm{KI}, \mathrm{KD}$, and learning objectives in the syllabus

\section{CONCLUSIONS}

The textbook on the structure and function of cells in the reproductive system material was effective with the construct validation value of 1 in the very high category. The result of validation showed the validity construct for the aspect of the presentation is 1 , the aspect of content is 1 , and the aspect of language is 1 . Then the criteria for each aspect are very high.

\section{ACKNOWLEDGMENT}

This research was funded through 2019 Applied Research with contract number 101/SP2H/LT/DRPM/2019 dated March 11, 2019, therefore many thanks were expressed to the Ministry of Research, Technology, Higher Education of the Republic of Indonesia. We would also like to thank the validator who worked hard to examine the contents of this textbook and provide many suggestions.

\section{REFERENCES}

Allehyani, B., Burnapp, D., \& Wilson, J. (2017). A Comparison of Teaching Materials (School 
Textbooks VS Authentic Materials) from The Perspective of English Teachers and Educational Supervisors in Saudi Arabia. International Journal of English Language and Linguistics Research, 5(2), 1-14.

Amir, M., Muris, \& Arsyad, M. (2015). Pengembangan Perangkat Pembelajaran Berbasis Pengalaman Pada Peserta Didik Kelas XI IPA SMA Negeri 9 Pinrang. Jurnal Sains dan Pendidikan Fisika, 11(3), 202-13.

Anisah, A., Azizah, E. N. (2016). Pengaruh Penggunaan Buku Teks Pelajaran dan Internet Sebagai Sumber Belajar Terhadap Hasil Belajar Siswa Pada Pembelajaran IPS (Eksperimen Kuasi Pada Kelas VII di SMP Negeri 1 Palimanan Kabupaten Cirebon). Jurnal Logika, 18(3), 1-18.

Asfiah, N., Mosik, \& Purwantoyo, E. (2013). Pengembangan Modul IPA Terpadu konstektual Pada tema bunyi. Unnes Science Education Journal, 2(1), 188-95.

BSNP. (2014). Instrumen Penilaian Buku Teks Pelajaran Biologi SMA/MA. Retrieved Mei 20, 2019, from http://bsnps indonesia.org/2014/05/28/instrumenpenilaian-buku-teks-pelajaran-tahun-2014/.

Chalkiadaki, A. (2018). A systematic literature review of 21 st-century skills and competencies in primary education, International Journal of Instruction, 11(3), 1-16.

Chamany, K., Allen, D., Tanner, K. (2008). Making Biology Learning Relevant to Students: Integrating People, History, and Context into College Biology Teaching. Life Science Education, 7, 267-278.

Daud, F. \& Rahmadana, A. (2015). Pengembangan Media Pembelajaran Biologi Berbasis E-Learning Pada Materi Ekskresi Kelas XI IPA 3 SMAN 4 Makassar. Jurnal Bionature, 16(1), 28-36.

Gregory, R. J. (2013). Tes Psikologi Sejarah, Prinsip, dan Aplikasi. Jakarta : Erlangga.

Mahmood, K. (2011). Conformity To Quality Characteristics of Textbooks: The Illusion of Textbook Evaluation in Pakistan. Journal of Research and Reflections in Education, 5(2), 170-190.

Nisa', A, Sudarmin, \& Samini. (2015). Efektivitas Penggunaan Modul Terintegrasi Etnosains Dalam Pembelajaran Berbasis Masalah Untuk Meningkatkan Literasi Sains Siswa. Unnes Science Education Journal, 4(3), 1049-56.

Ongsee, P. \& Nuangchalerm, P. (2019). Developing Critical Thinking of Grade 10 Students Through InquiryBased STEM learning, Jurnal Penelitian dan Pembelajaran IPA, 2(2), 132-141.
Padmapriya, P.V. (2015). Effectiveness of Self Learning Modules on Achievement in Biology among Secondary School Students. International Journal of Education and Psychological Research, 4(2). 446.

Panjaitan, R.G.P., Lijana, \& Wahyuni, E.S. (2019a). The Use of Comic as Learning Medium for Ecology. Unnes Science Education Journal, 8(1), 41-45.

Panjaitan, R. G. P., Sari, D.P., Wahyuni, E.S., \& Shidiq, G. A. $(2019 b)$. Feasibility of Human Excretory System Module in Biology Learning. Jurnal Penelitian dan Pembelajaran IPA, 5(1), 84-93.

Panjaitan, R.G. P., Titin, \& Santoso, R. (2019c). Film Dokumenter Pemanfaatan Tumbuhan Berkhasiat Obat sebagai Media Pembelajaran Materi Sistem Pencernaan. Jurnal Pendidikan Sains Indonesia, 7(2), 121-13.

Panjaitan, R.G.P., Wahyuni, E.S., \& Mega. (2019d). Film Dokumenter sebagai Media Pembelajaran Submateri Zat Aditif. Jurnal Pendidikan Biologi, 4(2), 52-59.

Pramana, D.W. \& Dewi, N.R. (2014). Pengembangan EBook IPA Terpadu Tema Suhu dan Pengukuran Untuk Menumbuhkan Kemandirian Belajar Siswa. Unnes Science Education Journal, 3(3), 602-08.

Purwanto, Y., \& Rizki, S. (2015). Pengembangan Bahan Ajar Berbasis Kontekstual pada Materi Himpunan Berbantu Video Pembelajaran. Jurnal Pendidikan Matematika, 4(1), 67-77.

Rahmawati, G. (2015). Buku Teks Pelajaran Sebagai Sumber Belajar Siswa di Perpustakaan Sekolah Di SMAN 3 Bandung. EduLib, 5(5), 102-113.

Sugiyono. (2015). Metode Penelitian Pendidikan Pendekatan Kuantitatif, Kualitatif, dan $R \& D$. Bandung: Alfabeta.

Suprapti \& Susanti, R. (2015). Pengembangan Modul Sistem Ekskresi Berbasis Inkuiri, Unnes Journal of Biology Education, 4(3), 237-43.

Suwarni, E. (2015). Pengembangan Buku Ajar Berbasis Lokal Materi Keanekaragaman Laba-Laba Di Kota Metro Sebagai Sumber Belajar Alternatif Biologi Untuk Siswa SMA Kelas X. Bioedukasi, 6(2), 8692.

Thang, S. M., Mustaffa, R., Wong, F. F., Noor, N. M., Mahmud, N., Latif, H., Aziz, M. S. A. (2013). A Quantitative Inquiry into the Effects of Blended Learning on English Language Learning: The Case of Malaysian Undergraduates. International Education Studies, 6(6), 1-7. 